\title{
Het Care4Care-arrest en de olievlekwerking van artikel 7:690 BW
}

mr. dr. Johan Zwemmer*

\section{Inleiding}

In het kader van de Wet flexibiliteit en zekerheid, die in werking trad op 1 januari 1999, werd an Titel 7.10 BW een bijzondere regeling van de uitzendovereenkomst toegevoegd waarin in artikel 7:690 $\mathrm{BW}$ onder meer een definitie is opgenomen van de uitzendovereenkomst als bijzondere arbeidsovereenkomst. Is aan de elementen uit deze definitie voldaan, dan wordt de uitzendwerkgever wettelijk geduid als de werkgever van de door hem aan opdrachtgevers ter beschikking gestelde werknemers. In dat geval is een 'verlicht ontslagregime' van toepassing op de arbeidsovereenkomst van de werknemer. Op grond hiervan bestaat gedurende de eerste 26 tot 78 weken een grote vrijheid de arbeidsovereenkomst te beëindigen en kunnen aansluitend tot een periode van vier jaar maximaal zes arbeidsovereenkomsten voor bepaalde tijd worden aangegaan met de werknemer.

Werknemers worden ook onder andere benamingen zoals 'detachering' en 'payrolling' ter beschikking gesteld van derden. Detachering en payrolling zijn niet gedefinieerd in het BW. Ook deze andere terbeschikkingstellingsvarianten kunnen kwalificeren als uitzendovereenkomst in de zin van artikel 7:690 BW. De regering heeft tijdens de parlementaire behandeling bevestigd dat de regeling van de uitzendovereenkomst niet alleen van toepassing zou zijn op kortdurende uitzending door uitzendbureaus bij 'piek of ziek'. Deze regeling zou ook gaan gelden voor het op dat moment - eind jaren negentig - in de praktijk voorkomende langduriger in- en uitlening door uitleen- en detacheerbedrijven. Ook bij de kwalificatie als uitzendwerkgever van zulke uitleen- en detacheerbedrijven zou echter, zo benadrukte de regering daarbij verschillende malen, van doorslaggevende betekenis zijn dat zij daadwerkelijk een allocatiefunctie op de arbeidsmarkt vervullen. Deze allocatiefunctie omschreef de regering als het bij elkaar brengen van de vraag naar en het aanbod van tijdelijke arbeid.

Johan Zwemmer is docent arbeidsrecht aan de Universiteit van Amsterdam en advocaat bij Stibbe te Amsterdam.

1. HR 4 november 2016, ECLI:NL:HR:2016:2356 (Care 4 Care Human Resources B.V./Stichting Pensioenfonds voor Personeelsdiensten 'StiPP').
In het Care4Care-arrest van 4 november $2016^{1}$ oordeelt de Hoge Raad dat op grond van artikel 7:690 BW niet vereist is dat de bij de derde te verrichten arbeid tijdelijk is, noch dat daarin een beperkende allocatiefunctie moet worden gelezen. In deze bijdrage ${ }^{2}$ zal allereerst worden ingegaan op de achtergrond en parlementaire geschiedenis van de regeling van de uitzendovereenkomst. Vervolgens worden de overwegingen van de Hoge Raad in het Care4Care-arrest besproken en worden de gevolgen van dit arrest geanalyseerd. Daarna wordt in het bijzonder aandacht besteed aan de gevolgen van het Care4Care-arrest voor intra-concern detachering en voor (het werkgeverschap bij) payrolling.

\section{De achtergrond van de wettelijke regeling van de uitzendovereenkomst}

Voorafgaand aan de inwerkingtreding van artikel 7:690 BW stond niet vast of de rechtsverhouding tussen het uitzendbureau en de uitzendkracht als arbeidsovereenkomst kon worden gekwalificeerd. De uitzendkracht was immers feitelijk niet werkzaam bij het uitzendbureau, maar bij en onder het feitelijke gezag van de inlener. ${ }^{3}$ Het uitzendbureau betaalde alleen het loon aan de uitzendkracht. In die tijd werd onderscheid gemaakt tussen kortdurend uitzenden door uitzendbureaus (dat aan een vergunning was gebonden) en het meer bestendige inen uitlenen van personeel door uitleen- of detacheerbedrijven. Het verschil tussen deze terbeschikkingstellingsvarianten bestond erin dat bij in- en uitlening een doorlopende arbeidsovereenkomst werd gesloten met de

2. Deze bijdrage vormt deels een bewerking van mijn hoofdstuk 17 'De uitzendkracht, de gedetacheerde en de payrollwerknemer' in: Bijzondere arbeidsverhoudingen (red.: Houweling/Van der Voet), Den Haag: Boom Juridische uitgevers 2017, tweede druk.

3. In arresten uit 1977, 1980 en 1988 kwalificeerde de Hoge Raad de rechtsverhouding tussen de uitzendkracht en het uitzendbureau of detacheerbedrijf als een arbeidsovereenkomst, omdat de uitzendkracht in die situaties op grond van de overeenkomst met het uitzendbureau of detacheerbedrijf verplicht was de werkzaamheden bij opdrachtgevers van het uitzendbureau of detacheerbedrijf te verrichten met inachtneming van de 'aanwijzingen' van die opdrachtgevers. Omdat het uitzendbureau of detacheerbedrijf in deze situatie het werkgeversgezag delegeerde aan de inlener, kon de rechtsverhouding met de uitzendkracht naar het oordeel van de Hoge Raad voldoen aan de definitie van art. 7:610 BW. Zie HR 14 oktober 1977, NJ 1978, 31, HR 23 mei 1980, NJ 1980, 633, m.nt. Stein, en HR 18 november 1988, NJ 1989, 344 
werknemer en dat bij uitzending alleen gedurende de termijn dat de uitzendkracht ter beschikking was gesteld aan een opdrachtgever een overeenkomst bestond met het uitzendbureau. In de jaren negentig vervaagde het onderscheid tussen uitzending en in- en uitlening echter, omdat ook uitzendbureaus zich op langduriger vormen van terbeschikkingstelling waren gaan richten. ${ }^{4}$

Met de inwerkingtreding in 1999 van de in artikel 7:690 BW opgenomen definitie van de uitzendovereenkomst kwam het onderscheid tussen het kortdurend uitzenden van personeel door uitzendbureaus en het meer bestendige in- en uitlenen van werknemers door uitleen- of detacheerbedrijven te vervallen. De regeling van de uitzendovereenkomst zou op al deze vormen van terbeschikkingstelling zien. De regering wees in dit verband op de toename van soms ook langer durende uitzendrelaties en de afschaffing van het vergunningstelsel. ${ }^{5}$ Met de regeling van de uitzendovereenkomst in het $\mathrm{BW}$ werd dus een ruimer toepassingsbereik beoogd dan de op dat moment - eind jaren negentig - in de praktijk voorkomende klassieke uitzending door uitzendbureaus die zich richtten op terbeschikkingstelling bij 'piek of ziek'. De regeling zou ook van toepassing zijn op andere organisaties, zoals uitleen- en detacheerbedrijven. Ook bij de kwalificatie als uitzendwerkgever ex artikel 7:690 BW van zulke uitleen- en detacheerbedrijven zou echter, zo benadrukte de regering verschillende malen, van doorslaggevende betekenis zijn dat zij daadwerkelijk een allocatiefunctie op de arbeidsmarkt vervullen. ${ }^{6}$ Deze allocatiefunctie werd echter niet met zoveel woorden opgenomen in de tekst van de definitie van artikel 7:690 BW.

4. Zie hierover par. 4.10.1 van mijn dissertatie: Pluraliteit van werkgeverschap, Deventer: Kluwer 2012.

5. Kamerstukken II 1996/97, 25263, 3, p. 9. Zie ook Kamerstukken II 1996/97, 25263, B, p. 8.

6. Kamerstukken I/ 1996/97, 25263, 3, p. 10 en p. 33, en 6, p. 16. Dit volgt ook uit het antwoord van de regering op kritische vragen die de Raad van State voorafgaande aan de parlementaire behandeling van de Wet flexibiliteit en zekerheid stelde over het ruime bereik van de definitie van de uitzendovereenkomst in art. 7:690 BW. De Raad van State vroeg zich af of het wel de bedoeling kon zijn dat niet alleen klassieke uitzending door uitzendbureaus, maar ook het meer bestendige in- en uitlenen van personeel door uitleen- of detacheerbedrijven onder deze definitie zou gaan vallen. De Raad van State meende dat bij uitlenen sprake was van een rechtsfiguur die een andere regeling vereiste dan het ter beschikking stellen van arbeidskrachten op basis van tijdelijke arbeidscontracten. Hij beval daarom aan de voorliggende regeling van de uitzendovereenkomst te beperken tot de uitzendrelatie 'in enge zin'. De regering ging hier echter niet mee en bevestigde dat beide terbeschikkingstellingsvarianten zouden gaan vallen onder art. 7:690 BW. De regering benadrukte daarbij echter dat het door de ter beschikking stellende werkgever vervullen van een allocatiefunctie op de arbeidsmarkt in alle gevallen vereist was voor 'toepassing van de uitzendovereenkomst' (zie Kamerstukken // 1996/97, 25263, B, p. 8-9 en 12).

\section{De definitie van de uitzendovereenkomst in artikel 7:690 BW}

In artikel 7:690 BW wordt de uitzendovereenkomst gedefinieerd als:

'de arbeidsovereenkomst waarbij de werknemer door de werkgever, in het kader van de uitoefening van het beroep of bedrijf van de werkgever ter beschikking wordt gesteld van een derde om krachtens een door deze aan de werkgever verstrekte opdracht arbeid te verrichten onder toezicht en leiding van de derde.'

Binnen deze definitie kunnen vier elementen worden onderscheiden: (i) er is een arbeidsovereenkomst tussen de ter beschikking stellende werkgever en de werknemer, (ii) de werknemer wordt in het kader van het beroep of bedrijf van de werkgever aan een derde ter beschikking gesteld voor het verrichten van arbeid, (iii) de terbeschikkingstelling vindt plaats krachtens een overeenkomst van opdracht tussen de (uitzend)werkgever en de derde, en (iv) de werknemer verricht de arbeid onder toezicht en leiding van de derde.

3.1. Arbeidsovereenkomst met uitzendwerkgever De aanwezigheid van een arbeidsovereenkomst van de (uitzend)werkgever met de werknemer vormt het startpunt in de definitie van artikel 7:690 BW. Over de juridische duiding van de uitzendrelatie deelde de regering mee dat deze als een arbeidsovereenkomst wordt aangemerkt en 'dit betekent dat op deze relatie de regeling van de arbeidsovereenkomst onverkort van toepassing is, behoudens voor zover anders bepaald. ${ }^{7}$ Later voegde de regering daar nog aan toe dat de uitzendovereenkomst in artikel 7:690 BW is gedefinieerd als een bijzondere arbeidsovereenkomst. ${ }^{8}$ Daarbij geldt ten aanzien van de elementen arbeid en gezag dat de werknemer in het kader van het beroep of bedrijf van de werkgever voor het verrichten van de bedongen arbeid aan een derde ter beschikking wordt gesteld waarbij de werknemer werkt onder toezicht en leiding van die derde. Bij twijfel over de vraag of sprake is van een uitzendovereenkomst moet, zo deelde de regering mee: 'het totale relevante feitencomplex aan de definitie van de uitzendovereenkomst getoetst (...) worden. Voldoen de feiten aan de in de definitie gegeven omstandigheden, dan kan een eventueel door partijen gegeven andere juridische duiding van de overeenkomst niet verhinderen dat de betreffende overeenkomst toch als arbeidsovereenkomst in de vorm van een uitzendovereenkomst aangemerkt dient te

7. Kamerstukken I/ 1996/97, 25263, 3, p. 9-10

8. In een brief aan de Tweede Kamer van 7 oktober 1997. Zie S.W. Kuip en C.G. Scholtens, Flexibiliteit en zekerheid, Parlementaire Geschiedenis van de Wet flexibiliteit en zekerheid, Deventer: Kluwer 1999, p. 950. 
worden.' ${ }^{9}$ Bij de kwalificatie van de uitzendovereenkomst ex artikel 7:690 BW, en bij de beantwoording van de vraag of daarbij een arbeidsovereenkomst tot stand is gekomen met de uitzendwerkgever, is dus op dezelfde wijze als bij de kwalificatie van de arbeidsovereenkomst van doorslaggevende betekenis op welke wijze partijen feitelijk uitvoering hebben gegeven aan de door hen gemaakte contractuele afspraken. ${ }^{10}$

\subsection{Terbeschikkingstelling in kader beroep of bedrijf uitzendwerkgever}

De uitzendwerkgever in de zin van artikel 7:690 BW moet zich in het kader van zijn beroep of bedrijf toeleggen op het ter beschikking stellen van werknemers aan derden. Dit betekent dat sprake is van een professionele organisatie die is gericht op het (tijdelijk) uitzenden van werknemers en niet van incidenteel ter beschikking stellen van arbeidskrachten door werkgevers die in feite geheel andersoortige beroeps- of bedrijfsactiviteiten hebben. ${ }^{11}$ Dat de uitzendwerkgever de werknemers in het kader van de uitoefening van zijn beroep of bedrijf ter beschikking stelt, werd door de wetgever gekoppeld aan de allocatiefunctie die de uitzendformule op de arbeidsmarkt vervulde. In de memorie van toelichting werd hierover het volgende medegedeeld:

'De terbeschikkingstelling moet geschieden in het kader van het beroep of het bedrijf van de werkgever. Dat betekent dat terbeschikkingstelling (een) doelstelling van de bedrijfs- of beroepsactiviteiten van de werkgever moet zijn; de toepasselijkheid van de uitzendovereenkomst is aldus gekoppeld aan de allocatieve functie van de werkgever.' 12

Allocatiefunctie betekent volgens de regering, het bij elkaar brengen van de vraag naar en het aanbod van tijdelijke arbeid:

'Het werken voor en via uitzendbureaus is de afgelopen jaren sterk in omvang toegenomen. De uitzend-

9. Zie S.W. Kuip en C.G. Scholtens, Flexibiliteit en zekerheid, Parlementaire Geschiedenis van de Wet flexibiliteit en zekerheid, Deventer: Kluwer 1999, p. 950. Zie hierover tevens par. 4.5.1 van mijn dissertatie.

10. Zie o.a. HR 14 november 1997, NJ 1998/149 (Groen/Schoevers), HR 10 oktober 2003, NJ 2007/446 (Van der Male B.V./Den Hoedt), HR 14 april 2006, NJ 2007/447 (Beurspromovendi/UvA), HR 10 december 2004, NJ 2005/239 (Diosynth B.V./Groot-van Veen), HR 15 december 2006, NJ 2007/448 (Van Houdts/BBO International), HR 13 juli 2007, NJ 2007/449 (STR/PGGM), HR 25 maart 2011, NJ 2011/594 m.nt. Verhulp, JAR 2011/109 m.nt. Loonstra en AR Updates 2011-0232 m.nt. Zwemmer ('De Gouden Kooi') en meer specifiek met betrekking tot de kwalificatie van de werkgever: HR 9 oktober 2015, NJ 2016/276 m.nt. Houweling en JAR 2015/277 m.nt. De Jong (Logidex).

11. Kamerstukken II 1996/97, 25263, 3, p. 10.

12. Kamerstukken II 1996/97, 25263, 3, p. 33. In haar antwoord op vragen van de Raad van State over het toepassingsbereik van de regeling van de uitzendovereenkomst koppelde de regering deze allocatiefunctie nog explicieter aan de woorden in het kader van de uitoefening van het beroep of bedrijf van de werkgever in art. 7:690 BW. Zij deelde daarover mee: 'Een ander element is dat de terbeschikkingstelling geschiedt in het kader van het beroep of bedrijf van de werkgever. Met andere woorden: terbeschikkingstelling moet doelstelling zijn van de beroeps of bedrijfsactiviteiten van de werkgever. Toepassing van de uitzendovereenkomst is aldus gekoppeld aan de allocatieve functie van de werkgever.' Kamerstukken II 1996/97, 25263, B, p. 12. formule vervult een belangrijke allocatiefunctie op de arbeidsmarkt t.w. het aldus bij elkaar brengen van de vraag naar en het aanbod van tijdelijke arbeid. Die functie moet behouden blijven. Tegelijkertijd is er in de praktijk behoefte aan grotere duidelijkheid gebleken voor wat betreft de rechtspositie van partijen betrokken bij de uitzendrelatie. Dat hangt samen met de vraag, of en wanneer er in geval van een uitzendrelatie sprake is van een arbeidsovereenkomst. ${ }^{13}$

Deze allocatiefunctie rechtvaardigt een verlicht ontslagregime bij uitzending:

'Het bijzondere karakter van de uitzendovereenkomst is gelegen in het feit dat de allocatieve functie van de uitzendovereenkomst impliceert dat partijen een zekere vrijheid hebben terzake van het aangaan en verbreken van hun arbeidsrelatie.'14

Vervolgens deelt de regering mee dat, hoewel met de regeling van de uitzendovereenkomst een ruimer toepassingsbereik werd beoogd dan de op dat moment in de praktijk voorkomende klassieke uitzending door uitzendbureaus die zich richten op terbeschikkingstelling bij 'piek of ziek', sprake dient te zijn van terbeschikkingstelling in het kader van zodanig beroep of bedrijf. Dat wil dus zeggen, door een uitzendwerkgever die een allocatiefunctie vervult op de arbeidsmarkt:

'De voorgestelde regeling voor de uitzendovereenkomst heeft niet alleen betrekking op de thans in de praktijk voorkomende uitzendrelatie, maar omvat ook alle andere driehoeksarbeidsrelaties, waarbij de werknemer in de uitoefening van het bedrijf of beroep van de werkgever aan een derde ter beschikking wordt gesteld, om onder leiding en toezicht van die derde arbeid te verrichten. Zodanige ter beschikkingstelling kan bijvoorbeeld ook uitlening omvatten, als die uitlening aan de elementen van de definitie voldoet. Is dat het geval, dan is het bijzondere regiem van de uitzendovereenkomst, zoals neergelegd in artikel 691 Boek 7 BW, op deze driehoeksarbeidsrelatie van toepassing. De voorgestelde regeling van de uitzendovereenkomst geeft derhalve een uniforme wettelijke regeling voor de vele onder verschillende benamingen in de praktijk voorkomende vormen van het ter beschikking stellen van arbeidskrachten, zoals: uitzenden, uitlenen, detacheren, of te werk stellen in het kader van een arbeidspool. Wel wijzen wij er nadrukkelijk op, dat de voorgestelde regeling beperkt is tot het ter beschikking stellen in het kader van zodanig beroep of bedrijf. In de praktijk gaat het dan dus alleen om organisaties zoals uitzendbureaus, detacheerbedrijven, arbeidspools en andere organisaties, die er hun beroep of bedrijf van maken arbeidskrachten onder welke noemer dan ook tijdelijk aan derden ter beschikking te stellen.' 15

13. Kamerstukken I/ 1996/97, 25263, 3, p. 9.

14. Kamerstukken I/ 1996/97, 25263, 3, p. 10.

15. Kamerstukken II 1996/97, 25263, 3, p. 10. 
En later nog duidelijker in de nota naar aanleiding van het verslag in antwoord op Kamervragen van de VVD:

'De leden van de VVD-fractie vroegen wat precies wordt bedoeld met de beperking van de uitzendrelatie tot die uitleners die bij de uitoefening van hun beroep of bedrijf arbeidskrachten ter beschikking stellen aan derden; of een ingenieursbureau, dat enkele personeelsleden elders detacheert, ook onder deze definitie valt, zo nee, waarom niet en zo ja, wat dit dan betekent voor de betreffende werknemers. De voorgestelde regeling van de uitzendovereenkomst geldt alleen voor die werkgevers die daadwerkelijk een allocatiefunctie op de arbeidsmarkt vervullen. Het gaat daarbij om werkgevers (intermediairs) die er hun bedrijf of beroep van maken om vraag en aanbod van tijdelijke arbeid bij elkaar te brengen. Het gaat in de praktijk dan om uitzendbureaus, detacheerbedrijven en arbeidspools.' 16

De uitzendwerkgever in de zin van artikel 7:690 BW moet zich op basis van de wetsgeschiedenis dus in het kader van een door hem op de arbeidsmarkt vervulde allocatiefunctie bedrijfsmatig richten op het bij elkaar brengen van de vraag naar en het aanbod van tijdelijke arbeid. $\mathrm{Nu}$ de regeling van de uitzendovereenkomst beperkt was tot terbeschikkingstelling in het kader van zodanig beroep of bedrijf van de uitzendwerkgever, zou de regeling van de uitzendovereenkomst volgens de regering in de praktijk alleen van toepassing zijn op uitzenden, uitlenen, detacheren of te werk stellen in het kader van een arbeidspool. ${ }^{17}$

Tijdens de parlementaire behandeling van de Wet werk en zekerheid herhaalde de regering dat het verlichte ontslagregime bij uitzending is gekoppeld aan de allocatiefunctie van de uitzendwerkgever. ${ }^{18} \mathrm{Zij}$ formuleerde dit als volgt:

'De allocatieve functie op de arbeidsmarkt brengt mee dat partijen bij een uitzendovereenkomst meer vrijheid krijgen bij het aangaan en beëindigen van de arbeidsovereenkomst.'19

Dat het beroep of bedrijf van de (uitzend)werkgever moet bestaan uit het bij elkaar brengen van de vraag naar en het aanbod van tijdelijke arbeid op de arbeidsmarkt volgt echter, als hiervoor gesteld, niet uit de tekst van artikel 7:690 $\mathrm{BW}$. In de (lagere) rechtspraak van de afgelopen jaren werd om deze reden wisselend geoordeeld over betekenis van deze allocatiefunctie bij de kwalificatie van de uitzendovereenkomst in de zin van artikel 7:690 BW. In de meeste gevallen werd onder ver-

16. Kamerstukken I/ 1996/97, 25263, 6, p. 15-16

17. Kamerstukken II 1996/97, 25263, 3, p. 10.

18. Overigens bleef de regeling van de uitzendovereenkomst, op enkele kleine wijzigingen na, ongemoeid in de Wet werk en zekerheid. Zie J.P.H. Zwemmer, 'Uitzenden, payrolling, schijnzelfstandigen en de Wet werk en zekerheid', ArbeidsRecht 2014/60.

19. Kamerstukken II 2013/14, 33818, 3, p. 20. Zie ook Kamerstukken II 2013/14, 33818, 7, p. 29. wijzing naar de hiervoor geciteerde wetsgeschiedenis geoordeeld dat het op de arbeidsmarkt vervullen van een allocatiefunctie door de werkgever een vereiste was voor het van toepassing zijn van de regeling van de uitzendovereenkomst. ${ }^{20}$ In andere uitspraken werd echter geoordeeld dat een allocatiefunctie geen vereiste was op basis van het ontbreken van deze allocatiefunctie in de tekst van de wet. Daarbij werd soms ook verwezen naar de hiervoor aangehaalde mededeling van de regering dat met de regeling van de uitzendovereenkomst een ruimer toepassingsbereik werd beoogd dan klassieke uitzending bij 'piek of ziek' ${ }^{21}$ Ook in de literatuur liepen langs deze lijnen de visies uiteen. ${ }^{22}$

\subsection{Terbeschikkingstelling krachtens opdrachtovereenkomst met inlener}

De terbeschikkingstelling van de uitzendwerknemer geschiedt op basis van een overeenkomst van opdracht van de (uitzend)werkgever met de derde. Uit de wetsgeschiedenis volgt dat in artikel 7:690 BW werd opgenomen dat de terbeschikkingstelling op grond van een overeenkomst van opdracht moet geschieden om duidelijk te maken dat bijvoorbeeld aanneming van werk niet tot een uitzendovereenkomst kan leiden. ${ }^{23}$ De overeenkomst van opdracht is evenals de arbeidsovereenkomst een in Boek 7 BW geregelde bijzondere overeenkomst. Op grond van artikel 7:400 lid $1 \mathrm{BW}$ mogen de in het kader van een opdrachtovereenkomst verrichte werkzaamheden niet bestaan uit het tot stand brengen van een werk van stoffelijke aard, het bewaren van zaken, het uitgeven van werken of het (doen) vervoeren van personen of zaken. In dat geval is sprake van een overeenkomst van aanneming van werk. ${ }^{24}$ Uit de wetsgeschiedenis volgt dat voor de toepassing van artikel 7:690 BW diensten die als pakket worden uitbesteed, zoals catering, beveiliging en schoonmaak, eveneens worden aangemerkt als verricht in het kader van een aangenomen werk waardoor hier geen sprake is van een uitzendovereenkomst. ${ }^{25}$

20. Zie Ktr. Enschede 21 maart 2013, ECLI:NL:RBONE:2013:BZ5108, Ktr Amsterdam 1 juli 2013, ECLI:NL:RBAMS:2013:6257, Ktr. Amsterdam 3 september 2013, ECLI:NL:RBAMS:2013:6063, Ktr. Amsterdam 22 september 2014, ECLI:NL:RBAMS:2014:6356, Ktr. Almelo 11 maart 2014, ECLI:NL:RBOVE:2014:1214, Hof Arnhem-Leeuwarden 3 februari 2015, ECLI:NL:GHARL:2015:670, Ktr. Assen 30 april 2015, ECLI:NL:RBNNE:2015:2205, Hof Den Haag 29 december 2015, ECLI:NL:GHDHA:2015:3820, Ktr. Assen 23 februari 2016, ECLI:NL:RBNNE:2016:692 en Rb. Limburg 2 augustus 2016, ECLI:NL:RBLIM:2016:6699.

21. Zie Rb. Amsterdam 1 juli 2010, ECLI:NL:RBAMS:2010:BN0820, Ktr Amsterdam 4 juli 2014, ECLI:NL:RBAMS:2014:5783, Hof Amsterdam 9 september 2014, ECLI:NL:GHAMS:2014:4616 en Hof Amsterdam 28 oktober 2014, ECLI:NL:GHAMS:2014:4547.

22. Zie voor een overzicht van de verschillende standpunten in de literatuur: Praktijkboek Flexibele Arbeidsrelaties, Deventer: Kluwer (losbl.), onderdeel I 5.2.5. en de noot van Knipschild onder JAR 2015/69.

23. Kamerstukken II 1996/97, 25263, 3, p. 33. Zie ook Kamerstukken II 1996/97, 25263, B, p. 12

24. Zie over het onderscheid tussen de overeenkomst van opdracht en die van aanneming van werk bij de kwalificatie van de uitzendovereenkomst, J.P.H. Zwemmer, 'Contracting en arbeidsrecht: over schijnconstructies, juridisch houdbare varianten en de gevolgen van de WAS en de WWZ', TAP 2015/118.

25. Zie par. 4.5 .3 van mijn dissertatie. 
3.4. Onder toezicht en leiding van de derde Tijdens de parlementaire behandeling van de Wet flexibiliteit en zekerheid werd niet toegelicht wat moest worden verstaan onder het verrichten van arbeid onder toezicht en leiding van de derde. In de literatuur werd aangenomen dat toezicht en leiding op hetzelfde neerkomen als werkgeversgezag in de zin van artikel 7:610 BW. In het hiervoor besproken Care4Care-arrest heeft de Hoge Raad overwogen dat de vraag of sprake is van toezicht en leiding als bedoeld in artikel 7:690 BW aan de hand van dezelfde maatstaven moet worden beantwoord als die gelden voor de beantwoording van de vraag of sprake is van een gezagsverhouding als bedoeld in artikel 7:610 BW. ${ }^{26}$ Beide begrippen dekken echter niet dezelfde lading. De gezagsverhouding op grond van artikel 7:610 BW is gebaseerd op een rechtsverhouding tussen degene die de arbeid verricht en degene voor wie arbeid wordt verricht. De uitzendwerknemer verbindt zich niet met de opdrachtgever van de uitzendwerkgever bij wie hij de arbeid verricht. De woorden onder toezicht en leiding in artikel 7:690 BW impliceren dat tussen de uitzendwerknemer en de opdrachtgever sprake is van een feitelijke gezagsverhouding zonder dat tussen hen een rechtsverhouding bestaat. De uitzendwerkgever heeft geen gezag over de feitelijke arbeid van de uitzendwerknemer. Wel heeft de uitzendwerknemer zich jegens de uitzendwerkgever verplicht arbeid te verrichten onder toezicht en leiding van de opdrachtgevers van de uitzendwerkgever. Bij dat laatste kan gesproken worden van een contractuele gezagsverhouding. In eerdere arresten heeft de Hoge Raad geoordeeld dat zowel het feitelijke gezag over de door de werknemer verrichte arbeid als het contractueel bedingen van zeggenschap over de door de werknemer verrichte arbeid een gezagsverhouding kan impliceren in de zin van artikel 7:610 BW. ${ }^{27}$ Op grond daarvan kan worden gesteld dat binnen de uitzendovereenkomst de gezagsverhouding is verdeeld in een contractuele en een feitelijke gezagsverhouding met respectievelijk de uitzendwerkgever en de opdrachtgever(s) van de uitzendwerkgever, waarbij de rechtsverhouding tussen de uitzendwerkgever en de uitzendwerknemer in artikel 7:690 BW juridisch is geduid als een arbeidsovereenkomst.

\section{Hoge Raad 4 november 2016}

In het Care4Care-arrest ${ }^{28}$ oordeelt de Hoge Raad onder verwijzing naar de tekst van artikel 7:690 BW en een deel van de hiervoor geciteerde wetsgeschiedenis dat op grond van artikel 7:690 $\mathrm{BW}$ niet vereist is dat de bij de derde te verrichten arbeid tijdelijk is, noch dat daarin een beperkende allocatiefunctie moet worden gelezen. De Hoge Raad overweegt hierover als volgt:

'Uit de totstandkomingsgeschiedenis van art. 7:690 BW kan niet worden afgeleid dat voor het aannemen van een uitzendovereenkomst andere vereisten gelden dan vermeld in deze bepaling. De tekst van art. 7:690 BW eist niet dat de bij de derde te verrichten arbeid tijdelijk is, noch impliceert deze een beperkende 'allocatiefunctie' als door het onderdeel wordt bepleit. Uit de toelichting op het artikel blijkt dat de wetgever heeft beoogd dat ook andere driehoeksrelaties dan de - kort gezegd - 'klassieke uitzendrelatie' onder de reikwijdte van de bepaling zouden vallen, mits aan de begripsomschrijving wordt voldaan (Kamerstukken II 1996-1997, 25 263, nr. 3, p. 9-10).'

De Hoge Raad wijst op de hiervoor onder 3.2 geciteerde passage uit de memorie van toelichting bij de Wet flexibiliteit en zekerheid waarin de regering meedeelde dat ook andere driehoeksrelaties dan klassieke uitzending onder de reikwijdte van artikel 7:690 BW zouden vallen. Daarbij laat de Hoge Raad echter onvermeld dat de regering in dit verband en ook later tijdens de parlementaire behandeling heeft benadrukt dat de regeling van de uitzendovereenkomst alleen zou gelden voor die werkgevers die daadwerkelijk een allocatiefunctie op de arbeidsmarkt vervullen. ${ }^{29}$ Bovendien lijkt de Hoge Raad zich niet te realiseren dat de door hem aangehaalde passage uit de wetsgeschiedenis moet worden geplaatst in de context van het op dat moment - eind jaren negentig - bestaande onderscheid tussen kortdurend uitzenden door uitzendbureaus met een vergunning en het meer bestendige in- en uitlenen van werknemers door uitleenen detacheerbedrijven (zie onder 2 hiervoor). Ook deze uitleen- en detacheerbedrijven vervulden doorgaans een allocatiefunctie op de arbeidsmarkt.
26. HR 4 november 2016, ECLI:NL:HR:2016:2356 (Care 4 Care Human Resources B.V./Stichting Pensioenfonds voor Personeelsdiensten 'StiPP').

27. Zie par. 2.3.2 van mijn dissertatie.
28. HR 4 november 2016, ECLI:NL:HR:2016:2356 (Care 4 Care Human Resources B.V./Stichting Pensioenfonds voor Personeelsdiensten 'StiPP'). In een fiscale procedure over de premiesectorindeling van een payrollbedrijf dat geen allocatiefunctie op de arbeidsmarkt vervulde, kwam de Hoge Raad op diezelfde datum tot een zelfde oordeel onder verwijzing naar het Care4Care-arrest. Zie HR 4 november 2016, ECLI:NL:HR:2016:2496.

29. Kamerstukken II 1996/97, 25263, 3, p. 10 en Kamerstukken II $1996 / 97,25263,6$, p. 16 


\subsection{Allocatiefunctie geen vereiste voor} toepassing artikel 7:690 $\mathrm{BW}$; verlicht ontslagregime van artikel 7:691 BW automatisch van toepassing

Op grond van het Care4Care-arrest vormt het door de werkgever vervullen van een allocatiefunctie op de arbeidsmarkt dus geen constitutief vereiste (meer) bij de kwalificatie van de uitzendovereenkomst ex artikel 7:690 BW. Ook de uitzendwerkgever in de zin van artikel 7:690 BW die geen allocatiefunctie vervult op de arbeidsmarkt kan daarmee gebruikmaken van het in artikel 7:691 BW neergelegde verlichte ontslagregime bij uitzending. Artikel 7:690 BW fungeert immers uitsluitend als toegangspoort naar het in artikel 7:691 BW opgenomen verlichte ontslagregime bij uitzending. ${ }^{30} \mathrm{Dit}$ laatste wordt uitdrukkelijk bevestigd door de Hoge Raad in het Care4Care-arrest:

'De wetsgeschiedenis biedt geen aanknopingspunt voor de veronderstelling dat de wetgever in art. 7:691 BW aan het begrip 'uitzendovereenkomst' een andere betekenis heeft willen geven dan in art. 7:690 BW. Gelet op de plaatsing van beide artikelen in een afzonderlijke afdeling in de wet, waarbij art. 7:690 BW de begripsomschrijving en art. 7:691 BW enkele regels geeft, ligt zo'n andere betekenis ook niet voor de hand.'

\subsection{Hoge Raad wijst naar wetgever}

De Hoge Raad lijkt er in zijn arrest desalniettemin rekening mee te houden dat zijn uitleg van artikel 7:690 BW op gespannen voet staat met de bedoelingen van de wetgever en overweegt over 'nieuwe driehoeksrelaties als payrolling' het volgende in zijn arrest:

'Voor zover de toepassing van de regels van art. 7:691 BW in nieuwe driehoeksrelaties als payrolling zou leiden tot resultaten die zich niet laten verenigen met hetgeen de wetgever bij de regeling van de art. 7:690-7:691 BW voor ogen heeft gestaan, is het in de eerste plaats aan de wetgever om hier grenzen te stellen. Dat neemt niet weg dat de rechter bij de toepassing de mogelijkheid heeft de regels van art. 7:691 BW zo uit te leggen dat strijd met de ratio van die regels wordt voorkomen, dan wel dat hij een beroep op die regels naar maatstaven van redelijkheid en billijkheid onaanvaardbaar kan oordelen. In het onderhavige geval is een en ander echter niet aan de orde.'

Het oordeel van de Hoge Raad over het toepassingsbereik van de regeling van de uitzendovereenkomst is duidelijk, maar moeilijk te verenigen met de hiervoor onder 3.2 geciteerde wetsgeschiedenis en de mededeling van de regering tijdens de parlementaire behandeling van de Wet werk en zekerheid dat het verlichte ontslagregime bij uitzending is gekoppeld aan de allocatiefunctie van

30. Zie par. 4.12.1 van mijn dissertatie. Sinds de inwerkingtreding van de Wet werk en zekerheid is het verlichte ontslagregime bij de uitzendovereenkomst eveneens opgenomen in art. 7:668a lid 5 onderdeel a BW. de uitzendwerkgever. De Hoge Raad had er op grond hiervan ook voor kunnen kiezen duidelijker stelling te nemen in plaats van te overwegen dat de wetgever in actie moet komen wanneer zijn - vooral op de tekst van artikel 7:690 BW gebaseerde - oordeel niet tot het door de wetgever beoogde resultaat zou leiden. ${ }^{31}$ De duidelijke overwegingen van de Hoge Raad over de onderlinge verhouding van de artikelen 7:690 en $691 \mathrm{BW}$ maken dat de door de Hoge Raad genoemde mogelijkheid voor de rechter om artikel 7:691 $\mathrm{BW}$ zo uit te leggen dat strijd met de ratio van die regels wordt voorkomen, dan wel dat hij een beroep op die regels naar maatstaven van redelijkheid en billijkheid onaanvaardbaar kan oordelen, in de praktijk geen betekenis zal hebben. Immers, als sprake is van een uitzendovereenkomst ex artikel 7:690 $\mathrm{BW}$, dan is naar het oordeel van de Hoge Raad het verlichte ontslagregime in artikel 7:691 BW van toepassing. Daar zit weinig licht tussen.

\subsection{Toezicht en leiding in artikel 7:690 BW}

betekent hetzelfde als een gezagsverhouding in artikel 7:610 BW

In het Care4Care-arrest overweegt de Hoge Raad ook dat de vraag of sprake is van toezicht en leiding als bedoeld in artikel 7:690 $\mathrm{BW}$ aan de hand van dezelfde maatstaven moet worden beantwoord als die gelden voor de beantwoording van de vraag of sprake is van een gezagsverhouding als bedoeld in artikel 7:610 BW. ${ }^{32}$ Zoals hiervoor opgemerkt, dekken beide begrippen echter niet dezelfde lading. De woorden onder toezicht en leiding in artikel 7:690 BW impliceren dat tussen de uitzendwerknemer en de opdrachtgever sprake is van een feitelijke gezagsverhouding zonder dat tussen hen een rechtsverhouding bestaat. De uitzendwerknemer heeft zich jegens de uitzendwerkgever verplicht arbeid te verrichten onder toezicht en leiding van de opdrachtgevers van de uitzendwerkgever. Bij dat laatste kan gesproken

31. In zijn - op dit punt niet door de Hoge Raad gevolgde - conclusie voor het Care4Care-arrest (ECLI:NL:PHR:2016:238) onderscheidde A-G Van Peursem twee soorten uitzendovereenkomsten en introduceerde hij in dat kader een zogenoemde 'traditionele' of 'klassieke' allocatiefunctie die zou inhouden: 'het actief bij elkaar brengen van vraag en aanbod op de arbeidsmarkt van (in de regel) werk van tijdelijke aard, ook wel aangeduid als het opvangen van "ziek of piek" en een "ruime" allocatiefunctie die zou inhouden dat de werkgever zich "bedrijfs- of beroepsmatig bezighoudt met de terbeschikkingstelling van werknemers aan opdrachtgevers"' (punt 3.8). Ook bij deze ruime allocatiefunctie diende volgens de A-G 'wel een vorm over te blijven van allocatie op de arbeidsmarkt in deze ruim opgevatte zin'. Dat zou volgens de A-G bijvoorbeeld niet aan de orde zijn wanneer sprake is van payrolling 'waarbij de payroller in feite alle - oneerbiedig gezegd - "personeelssores" overneemt van de "inlener", waar geen allocatieve functie op de arbeidsmarkt in welke ruime zin dan ook meer valt te ontwaren, maar er sprake is van een formeel werkgeverschap van de payroller volgens de arbeidsvoorwaarden van de opdrachtgever/ "inlener" (permanente overname van arbeidscontracten)' (punt 3.30). Bij deze vorm van payrolling zou volgens de A-G geen sprake zijn van uitzending ex art. 7:690 BW. In de woorden van de A-G: 'De payrol/werkgever speelt dan geen enkele rol bij het bij elkaar brengen van vraag en aanbod op de arbeidsmarkt, zo zou men kunnen zeggen, maar slechts bij de formele en administratieve uitvoering van de overeenkomsten.'

32. HR 4 november 2016, ECLI:NL:HR:2016:2356 (Care 4 Care Human Resources B.V./Stichting Pensioenfonds voor Personeelsdiensten 'StiPP'). 
worden van een contractuele gezagsverhouding. In eerdere arresten heeft de Hoge Raad geoordeeld dat zowel het feitelijke gezag over de door de werknemer verrichte arbeid als het contractueel bedingen van zeggenschap over de door de werknemer verrichte arbeid een gezagsverhouding kan impliceren in de zin van artikel 7:610 BW.

Een verklaring voor deze overweging van de Hoge Raad over de betekenis van toezicht en leiding in het Care4Care-arrest kan liggen in het feit dat Care4Care had gesteld dat het bij de door haar aan zorginstellingen ter beschikking gestelde werknemers ging om hoogopgeleide, gekwalificeerde en deskundige specialisten. Wellicht heeft de Hoge Raad met zijn overweging willen bevestigen dat ook in dat geval, net zoals bij een gewone arbeidsovereenkomst, sprake kan zijn van een gezagsverhouding. Overigens had het Hof Amsterdam in eerdere instantie onder verwijzing naar een contractuele afspraak in de door Care4Care gehanteerde mantelovereenkomst waarin de instructiebevoegdheid was overgedragen aan de derde, geoordeeld dat de werknemers van Care4Care de werkzaamheden onder toezicht en leiding van de zorginstellingen verrichtten. ${ }^{33}$ De door Care4Care genoemde feitelijke omstandigheden, dat de werknemers gespecialiseerde werkzaamheden overeenkomstig hun eigen professionele standaarden verrichtten, de zorginstellingen ter zake zelf over onvoldoende kennis beschikten én dat de werknemers begeleid werden door een tweetal accountmanagers in dienst van

Care4Care, werden daarbij door het hof gepasseerd. Dat het hof bij de beantwoording van de vraag of sprake is van toezicht en leiding in de zin van artikel 7:690 BW meer waarde lijkt te hechten aan contractuele afspraken dan aan de wijze waarop hier feitelijk uitvoering werd gegeven, laat zich moeilijk verenigen met het dwingendrechtelijke karakter van dit artikel.

\section{Gevolgen Care4Care-arrest}

\subsection{Verlicht ontslagregime ook van toepassing op driehoeksrelaties waarbij ter beschikking stellende werkgever geen allocatiefunctie vervult}

Op de uitzendovereenkomst zijn de in de artikelen 7:691 BW en 7:668a lid 5 onderdeel a BW opgenomen bijzondere regels van toepassing. Artikel 7:691 lid 1 BW bepaalt dat de ketenregeling van artikel 7:668a BW pas op de uitzendovereenkomst van toepassing is nadat de uitzendwerknemer in meer dan 26 weken arbeid heeft verricht in het kader van de uitzendovereenkomst. $\mathrm{Na}$ deze periode is de ketenregeling van toepassing. Op grond van artikel 7:691 lid 2 BW kan in de arbeidsovereenkomst een uitzendbeding worden opgenomen waardoor de uitzendovereenkomst van rechtswege eindigt als de terbeschikkingstelling van de werknemer aan de

33. Hof Amsterdam 28 oktober 2014, ECLI:NL:GHAMS:2014:4547. opdrachtgever op verzoek van de opdrachtgever eindigt. Op zijn beurt mag de werknemer de arbeidsovereenkomst zonder opgave van redenen onverwijld opzeggen wanneer een dergelijk uitzendbeding is opgenomen in de arbeidsovereenkomst. Het uitzendbeding geldt echter slechts gedurende de eerste 26 weken waarin de werknemer arbeid heeft verricht op basis van de uitzendovereenkomst (artikel 7:691 lid 3 BW). Na afloop van deze periode eindigt de arbeidsovereenkomst niet meer van rechtswege wanneer de terbeschikkingstelling op verzoek van de inlener eindigt en kan de werknemer de arbeidsovereenkomst ook niet meer per direct opzeggen. Bij de berekening van de hiervoor genoemde weken en maanden worden perioden waarin arbeid wordt verricht die elkaar opvolgen met tussenpozen van ten hoogste zes maanden samengeteld. ${ }^{34}$ Op grond van artikel 7:691 lid $5 \mathrm{BW}$ worden perioden waarin voor verschillende werkgevers arbeid wordt verricht die ten aanzien van de verrichte arbeid redelijkerwijze geacht moeten worden elkaars opvolger te zijn mede in aanmerking genomen bij de toepassing van artikel 7:691 lid $1 \mathrm{t} / \mathrm{m} 3 \mathrm{BW} .{ }^{35}$ Artikel 7:691 lid 8 onderdeel a BW maakt mogelijk dat tot een periode van ten hoogste 78 weken bij cao van de in dit artikel genoemde termijn van 26 weken wordt afgeweken. Voorts kan op grond van dit artikel - in afwijking van artikel 7:628 $\mathrm{BW}$ - bij cao worden afgesproken dat de werknemer tot een periode van ten hoogste 78 weken geen recht heeft op een naar tijdruimte vastgesteld loon. ${ }^{36} \mathrm{Na}$ afloop van de periode van 26 tot 78 weken in artikel 7:691 BW kan op grond van artikel 7:668a lid 5 onderdeel a BW in geval van uitzending de periode van 24 maanden in artikel 7:668a lid 1 sub a BW bij cao worden verlengd tot ten hoogste 48 maanden en kan het aantal van drie contracten worden verhoogd naar ten hoogste zes. Daardoor kunnen met de werknemer gedurende een aaneengesloten periode van vijfenhalf jaar flexibele arbeidsovereenkomsten worden gesloten.

\subsection{ABU-cao na november 2017 niet meer algemeen verbindend?}

In artikel 13 van de $\mathrm{ABU}$-cao is een systeem van drie fasen overeengekomen. ${ }^{37}$ In de eerste fase $\mathrm{A}$ is de in artikel 7:691 BW gehanteerde termijn van 26 weken uitgebreid naar 78 weken. Gedurende de daaropvolgende tweede fase B kunnen in afwijking van artikel 7:668a $\mathrm{BW}$ gedurende vier jaar maximaal zes (van rechtswege eindigende) arbeidsovereenkomsten voor bepaalde tijd met de werknemer worden gesloten. In de daaropvolgende derde fase $\mathrm{C}$ is de werknemer voor onbepaalde tijd in dienst (getreden) bij de uitzendwerkgever. ${ }^{38}$

34. Art. 7:691 lid 4 BW.

35. Op grond van art. 7:691 lid 8 onderdeel b BW kan bij cao ten nadele van de werknemer worden afgeweken van dit artikel.

36. Art. 7:691 lid 7 jo. lid 8 onderdeel a BW.

37. CAO voor Uitzendkrachten 2012-2017, versie september 2016. Deze cao is door FNV Bondgenoten, CNV Dienstenbond, De Unie en LBV afgesloten met de Algemene Bond Uitzendondernemingen.

38. In de andere bedrijfstak-cao binnen de uitzendsector, de met de Nederlandse Bond van Bemiddelings- en Uitzendondernemingen gesloten NBBU-cao wordt een vergelijkbaar fasensysteem gehanteerd. 
Indien de werknemer gedurende een periode van meer dan zes maanden geen arbeid verricht, begint de telling opnieuw vanaf het begin van fase A. De ABU-cao is van toepassing op uitzendovereenkomsten in de zin van artikel 7:690 BW tussen uitzendkrachten en een uitzendonderneming indien en voor zover de omvang van de uitzendloonsom ten minste $50 \%$ van het totale premieplichtig loon op jaarbasis van die uitzendonderneming bedraagt. ${ }^{39}$ De huidige ABU-cao is algemeen verbindend verklaard tot en met 4 november $2017 .{ }^{40} \mathrm{Nu}$ de allocatiefunctie geen vereiste (meer) is voor de toepassing van de definitie van artikel 7:690 $\mathrm{BW}$, is het aantal ondernemingen dat onder de werkingssfeer van de ABU-cao valt dusdanig toegenomen dat de werkingssfeer in het kader van een nieuwe algemeenverbindendverklaring specifieker zal moeten worden omschreven om te voldoen aan het representativiteitsvereiste in het Toetsingskader Algemeen Verbindend Verklaring CAO-bepalingen. ${ }^{41}$

\section{Payrolling}

De Vereniging Payroll Ondernemingen (VPO), de branchevereniging die de belangen van de aangesloten payrollondernemingen behartigt en die per 1 januari 2016 is opgegaan in de ABU, heeft zich op het standpunt gesteld dat payrolling een 'bijzondere vorm' is van de uitzendovereenkomst in de zin van artikel 7:690 BW. ${ }^{42}$ Op de website van de ABU wordt payrolling als volgt omschreven:

'Payrolling betreft een gespecialiseerde vorm van hrdienstverlening, waarbij opdrachtgevers zelf verantwoordelijk zijn voor de werving, selectie en begeleiding van werknemers. Een payrollorganisatie stelt werknemers ter beschikking aan een opdrachtgever om onder diens leiding en toezicht te werken. Het doel van payrolling is dat de payrollonderneming het juridisch werkgeverschap zoveel mogelijk overneemt van de opdrachtgever. Hieronder vallen bijvoorbeeld administratieve en financiële verplichtingen die verbonden zijn aan bijvoorbeeld disfunctioneren, ziekte, arbeidsongeschiktheid en verlof.'

$\mathrm{Nu}$ de Hoge Raad heeft geoordeeld dat het vervullen van een allocatiefunctie op de arbeidsmarkt geen constitutief vereiste (meer) vormt bij de kwalificatie van de uitzendovereenkomst ex artikel 7:690 BW, zou ook bij payrolling sprake kunnen zijn van een uitzendovereenkomst. ${ }^{43}$ In dat geval zijn ook bij payrolling het in artikel 7:691 BW neergelegde verlichte ontslagregime bij uitzending en (in beginsel) de ABU-cao van toepassing. De

39. Zie art. 1 jo. art. 2 lid $1 \mathrm{ABU}$-cao

40. Stcrt. 2016, 15865 .

41. Zie par. 4.1 van het Toetsingskader Algemeen Verbindend Verklaring CAO-bepalingen.

42. Zie art. 8.1 van de voormalige VPO-arbeidsvoorwaardenregeling.

43. Zie HR 2 december 2016, ECLI:NL:HR:2016:2757. payrollwerknemer zou dan voor de toepassing van Titel 7.10 BW in dezelfde juridische positie verkeren als een uitzendkracht, zij het dat het payrollbedrijf - dat geen allocatiefunctie vervult op de arbeidsmarkt - de werknemer bij het einde van de inleenopdracht niet ter beschikking zal (kunnen) stellen aan een andere opdrachtgever.

\subsection{Payrolling en het werkgeverschap}

Dat op grond van artikel 7:690 BW niet vereist is dat de werkgever een allocatiefunctie vervult op de arbeidsmarkt, betekent niet dat daarmee vaststaat dat bij payrolling telkens sprake is van een uitzendovereenkomst waarbij de werknemer op basis van een arbeidsovereenkomst in dienst is van het payrollbedrijf. Artikel 7:690 $\mathrm{BW}$ is, evenals artikel 7:610 $\mathrm{BW}$, van dwingend recht. Partijen kunnen niet contractueel afspreken dat bij payrolling sprake is van een uitzendovereenkomst ex artikel 7:690 BW. Dat het payrollbedrijf en de werknemer een schriftelijke arbeidsovereenkomst ondertekenen, impliceert niet dat daarmee tussen hen een arbeidsovereenkomst tot stand is gekomen en het payrollbedrijf voor de toepassing van artikel 7:690 BW kwalificeert als een werkgever die zijn werknemer ter beschikking stelt. ${ }^{44}$ In een reeks arresten sinds 1997 heeft de Hoge Raad bevestigd en in verschillende situaties uitgewerkt dat wanneer de contractuele afspraken van meet af aan niet corresponderen met de feitelijke uitvoering, hier bij de kwalificatie van de arbeidsovereenkomst doorheen moet worden gekeken. ${ }^{45}$ 'Wezen' gaat dan voor 'schijn'. Dat geldt ook bij de kwalificatie van de uitzendovereenkomst (zie onder 3.1 hiervoor). Op grond van deze arresten is van belang de wijze waarop partijen zich bij de uitvoering van de overeenkomst feitelijk tegenover elkaar hebben gedragen en of dit correspondeert met de wijze waarop zij hun (contractuele) verhouding (stellen te) hebben ingericht. Stemmen de door partijen gemaakte afspraken bij het aangaan van de overeenkomst niet overeen met de wijze waarop zij zich vervolgens bij de feitelijke uitvoering van de overeenkomst tegenover elkaar hebben gedragen, dan kan voorbijgaand aan de door partijen gemaakte contractuele afspraken worden geoordeeld dat geen sprake is van een uitzendovereenkomst. In mijn dissertatie heb ik onder verwijzing naar deze arresten van de Hoge Raad betoogd dat ook bij de kwalificatie van de werkgever in arbeidsrechtelijke driehoeksverhoudingen alleen dan betekenis toekomt aan de door partijen gemaakte contractuele afspraken wanneer deze corresponderen met de wijze waarop hieraan vervolgens feitelijk uitvoering is gegeven. ${ }^{46}$ Dat betekent dat de

44. Vgl. HR 10 oktober 2003, NJ 2007/446 (Van der Male B.V./Den Hoedt).

45. Zie o.a. HR 14 november 1997, NJ 1998/149 (Groen/Schoevers), HR 10 oktober 2003, NJ 2007/446 (Van der Male B.V./Den Hoedt), HR 14 april 2006, NJ 2007/447 (Beurspromovendi/UvA), HR 10 december 2004, NJ 2005/239 (Diosynth B.V./Groot-van Veen), HR 15 december 2006, NJ 2007/448 (Van Houdts/BBO International), HR 13 juli 2007, NJ 2007/449 (STR/PGGM), HR 25 maart 2011, NJ 2011/594 m.nt. Verhulp, JAR 2011/109 m.nt. Loonstra en AR Updates 2011-0232 m.nt. Zwemmer ('De Gouden Kooi') en meer specifiek met betrekking tot de kwalificatie van de werkgever: HR 9 oktober 2015, NJ 2016/276 m.nt. Houweling en JAR 2015/277 m.nt. De Jong (Logidex).

46. Zie par. 2.3.5 van mijn dissertatie. 
contractuele werkgever binnen de arbeidsrechtelijke driehoeksverhouding naar mijn mening slechts als de werkgever kan worden gekwalificeerd wanneer deze een voldoende zelfstandige en inhoudelijke rol speelt bij de totstandkoming en de uitvoering van de arbeidsovereenkomst. Is dat niet het geval, en werd feitelijk van meet af aan een arbeidsovereenkomst met de opdrachtgever (feitelijke werkgever) beoogd, dan is de werknemer op grond van artikel 7:610 BW in dienst bij de opdrachtgever. ${ }^{47}$ De omstandigheid dat in deze situatie een schriftelijke overeenkomst ontbreekt tussen de werknemer en de opdrachtgever staat er in verband met het dwingendrechtelijke karakter van artikel 7:610 $\mathrm{BW}$ niet aan in de weg dat kan worden geoordeeld dat tussen hen een arbeidsovereenkomst tot stand is gekomen. Dat is niet anders wanneer de werknemer goed geïnformeerd akkoord is gegaan met de payrollconstructie, zo volgt uit het arrest Stichting Thuiszorg Rotterdam/PGGM. ${ }^{48}$ A-G Timmerman verwoordt dit aldus in zijn conclusie voor dit arrest:

'De betrokken partijen kunnen een constructie met tussenschakeling van een andere partij op papier hebben gezet die - alle omstandigheden in aanmerking nemend - niet in overeenstemming is met hetgeen zij werkelijk bedoelden af te spreken. In een dergelijk geval is niet de schriftelijke tekst waarin de betrokken rechtsverhoudingen zijn weergegeven, maar de bedoeling van partijen doorslaggevend. Hierbij speelt ook een rol dat de definitie van de arbeidsovereenkomst in artikel 7:610 $\mathrm{BW}$ van dwingend recht is. Om die definitie kunnen partijen niet zomaar heen wandelen.'

Het is de vraag of bij de thans meest gebruikelijke vorm van payrolling een arbeidsovereenkomst tot stand komt tussen het payrollbedrijf en de werknemer en daarmee of sprake is van terbeschikkingstelling van een werknemer van het payrollbedrijf aan de opdrachtgever in de zin van artikel 7:690 BW. Hoewel het payrollbedrijf geen allocatiefunctie hoeft te vervullen op de arbeidsmarkt, moet dit wel een voldoende zelfstandige rol spelen bij de totstandkoming en uitvoering van de arbeidsovereenkomst van de werknemer. In dat verband kan worden geconstateerd dat bij payrolling het payrollbedrijf een overeenkomst van opdracht sluit met de opdrachtgever waarin wordt afgesproken dat het payrollbedrijf de door deze opdrachtgever geworven werknemer in dienst neemt en aan de opdrachtgever ter beschikking gaat stellen. De payrollconstructie wordt opgezet omdat de opdrachtgever - een onderneming of overheidsinstelling - niet de juridische en administratieve werkgever wil zijn van 'zijn' werknemers. Daarom

47. Omdat de werknemer en de opdrachtgever in werkelijkheid van meet af aan een arbeidsovereenkomst met elkaar beogen, zou hier - anders dan aan de orde was in het arrest ABN AMRO/Malhi (HR 5 april 2002, NJ 2003, 124) - de vraag wanneer gedurende de looptijd van de overeenkomst de opdrachtgever het payrollbedrijf als werkgever is gaan vervangen - en zich als zodanig met de werknemer heeft verbonden niet relevant zijn.

48. HR 13 juli 2007, NJ 2007, 449 (Stichting Thuiszorg Rotterdam/PGGM). geeft hij dit uit handen aan een payrollbedrijf. Met dit doel sluit het payrollbedrijf een schriftelijke arbeidsovereenkomst met de werknemer en is het payrollbedrijf verantwoordelijk voor de nakoming van de aan de arbeidsovereenkomst verbonden juridische en administratieve verplichtingen. Of gelet op deze bedoelingen van partijen kan worden aangenomen dat een arbeidsovereenkomst tot stand komt met het payrollbedrijf, en in het verlengde daarvan een uitzendovereenkomst ex artikel 7:690 BW, valt te betwijfelen. De werknemers staan weliswaar op de loonlijst bij het payrollbedrijf en werken onder het gezag van de opdrachtgever, maar dat neemt niet weg dat de payrollconstructie wordt opgezet omdat de opdrachtgever 'op papier' niet, maar feitelijk wel de werkgever wil zijn van 'zijn' werknemers.

In de (lagere) rechtspraak van de afgelopen jaren over de arbeidsrechtelijke kwalificatie van payrolling is om deze reden geoordeeld dat door de payrollconstructie moet worden heengekeken bij de kwalificatie van de werkgever. ${ }^{49}$ De opdrachtgever werd dan, ondanks de door de werknemer met het payrollbedrijf gesloten schriftelijke arbeidsovereenkomst, gekwalificeerd als de werkgever ex artikel 7:610 BW van de werknemer. In andere gevallen werd echter op basis van de door partijen gemaakte contractuele afspraken geoordeeld dat de werknemer een arbeids- of uitzendovereenkomst had met het payrollbedrijf. ${ }^{50}$ In veel van deze uitspraken speelde bij de beoordeling van het werkgeverschap van het payrollbedrijf voor de rechter een rol dat het payrollbedrijf geen allocatiefunctie vervult op de arbeidsmarkt.

\subsection{Ingrijpen wetgever op het gebied van ontslagbescherming payrollwerknemer?}

Zoals hiervoor uiteengezet, betekent het feit dat de allocatiefunctie op grond van het Care4Care-arrest niet hoeft te worden gelezen in de definitie van artikel 7:690 BW niet dat daarmee gegeven is dat bij payrolling telkens sprake is van een uitzendovereenkomst ex artikel 7:690 BW. Wanneer het payrollbedrijf zowel bij de totstandkoming als bij de uitvoering van de arbeidsovereenkomst met de payrollwerknemer uitsluitend fungeert als 'contractueel verlengstuk' van de opdrachtgever, kan de rechter nog steeds door de payrollconstructie heen kijken en oordelen dat de werknemer in dienst is (gebleven) van de opdrachtgever. Wanneer echter de dienst-

49. Ktr. Groningen 15 december 2009, JAR 2010/27, Ktr. Leeuwarden 12oktober 2012, ECLI:NL:RBLEE:2012:BY0861, JAR 2012/284, Ktr. Almelo 21 maart 2013, ECLI:NL:RBONE:2013:BZ5108, JAR 2013/95, Ktr. Almelo 13 mei 2013, ECLI:NL:RBOVE:2013:CA1178, JAR 2013/144, Rb. Den Haag 26 juni 2013, ECLI:NL:RBDHA:2013:7749, JAR 2013/193, Ktr. Amsterdam 3 september 2013, ECLI:NL:RBAMS: 2013:6063, JAR 2013/252, Ktr. Almelo 11 maart 2014, ECLI:NL:RBOVE:2014:1214, JAR 2014/95, Hof Arnhem-Leeuwarden 25 maart 2014, ECLI:NL:GHARL:2014:2340, JAR 2014/123, Ktr. Assen 1 mei 2015 ECLI:NL:RBNNE:2015:2205, JAR 2015/142, Hof Den Haag 29 december 2015, ECLI:NL:GHDHA:2015:3820, RAR 2016/52, Ktr. Assen 23 februari 2016, ECLI:NL:RBNNE:2016:692, RAR 2016/141 en Rb. Limburg 2 augustus 2016, ECLI:NL:RBLIM:2016:6699, AR Updates 2016-0899.

50. Hof Leeuwarden 23 maart 2010, ECLI:NL:GHLEE:2010:BL9881, JAR 2010/107, Ktr. Rotterdam 21 december 2012, JAR 2013/46 en Ktr. Amsterdam 4 juli 2014, ECLI:NL:RBAMS:2014:5783, JAR 2014/248. 
verlening door het payrollbedrijf niet uitsluitend gericht is op het door de opdrachtgever uit handen geven van de aan het juridisch werkgeverschap verbonden verplichtingen, zou sprake kunnen zijn van een arbeidsovereenkomst tussen het payrollbedrijf en de werknemer en daarmee - in lijn met het Care4Care-arrest - van een uitzendovereenkomst. Waar het bij een overheidsinstelling of grote onderneming de vraag zal zijn waarom een payrollconstructie nodig is, zou daarvan in het midden- en kleinbedrijf wel zelfstandige inhoud en betekenis kunnen uitgaan. Dan zou het werkgeverschap van het payrollbedrijf eveneens van toegevoegde waarde kunnen zijn voor de werknemer. Dat zou bijvoorbeeld het geval kunnen zijn wanneer payrollbedrijven zorg gaan dragen voor, en knowhow gaan ontwikkelen op het gebied van, onder meer de (tussentijdse) scholing van de payrollwerknemer, de herplaatsing van de payrollwerknemer (bijvoorbeeld in de vorm van arbeidspools) en, in geval van arbeidsongeschiktheid, de re-integratie van de payrollwerknemer. ${ }^{51}$ Omdat dan sprake is van een uitzendovereenkomst en het daarbij horende verlichte ontslagregime van toepassing is, kunnen met de payrollwerknemer in beginsel gedurende vijfenhalf jaar flexibele arbeidsovereenkomsten worden gesloten. Anders dan voor een echte uitzendkracht zal daarbij einde inleenopdracht voor de payrollwerknemer al snel einde arbeidsovereenkomst betekenen, omdat hij niet in dienst is van een uitzendwerkgever met een allocatiefunctie op de arbeidsmarkt. De bijzondere ontslagregels bij payrolling in de Ontslagregeling ${ }^{52}$ helpen de payrollwerknemer hier niet omdat deze uitsluitend van toepassing zijn bij de opzegging van de arbeidsovereenkomst (voor onbepaalde tijd) van de payrollwerknemer. ${ }^{53}$

Naar aanleiding van de overweging van de Hoge Raad, dat de wetgever in actie moet komen wanneer zijn oordeel in nieuwe driehoeksrelaties als payrolling zou leiden tot resultaten die niet verenigbaar zijn met wat de wetgever voor ogen heeft gestaan bij de regeling van de uitzendovereenkomst, zijn Kamervragen gesteld over de gevolgen van dit arrest. ${ }^{54}$ Daarbij deelde de minister van SZW over het toepassingsbereik van het verlichte ontslagregime bij uitzending mee:

'Het lichter arbeidsrechtelijk regime op grond van artikel 7:691 BW is, zoals ook uit de wetsgeschiedenis kan worden afgeleid, bedoeld voor het zogenoemde traditionele uitzenden waarbij sprake is van het samenbrengen van vraag en aanbod op de arbeidsmarkt voor het verrichten van in beginsel kortdurende tijdelijke werkzaamheden, zoals vervanging bij ziekte of zwangerschap of het opvangen van tijdelijke pieken in de productie. De Hoge Raad heeft echter geoordeeld dat ook voor toepassing van artikel 7:691

51. Zie p. 347 van mijn dissertatie.

52. Zie artikel $20 \mathrm{t} / \mathrm{m} 23$ Ontslagregeling.

53. Zie over deze ontslagregels J.M. van Slooten, I. Zaal \& J.P.H. Zwemmer, Handboek Nieuw ontslagrecht, Deventer: Kluwer 2015, hoofdstuk 3.3.

54. Aanhangsel Handelingen I/ 2016/17, 654. Zie ook de brief van de minister van SZW aan de Tweede Kamer van 5 december 2016, Kamerstukken II 2016/17, 29544, 761.
BW geen allocatiefunctie in voornoemde zin vereist is.'

Op de vraag aan de minister of hij de bezorgdheid van de Kamerleden deelde dat het Care4Care-arrest zou leiden tot meer onzekere arbeidscontracten en, zo ja, wat hij daaraan zou gaan doen, antwoordde de minister dat dit arrest voor werkgevers aanleiding kan zijn om nog meer gebruik te gaan maken van payrolling dan nu al het geval is. Een wetswijziging om de onwenselijke resultaten als gevolg van het oordeel van de Hoge Raad weg te nemen zou echter niet meer in zijn kabinetsperiode verwezenlijkt kunnen worden. Daarover zullen in een volgend regeerakkoord afspraken gemaakt moeten worden, aldus de minister.

\section{Intra-concern detachering}

Bij vooral grotere groepen of concerns zijn alle bij de verschillende groepsmaatschappijen werkzame werknemers in dienst bij één groepsmaatschappij. Vaak is dit een speciaal met dat doel opgerichte rechtspersoon die binnen de groep als centrale werkgever of 'personeelsbv' fungeert. Deze uitzend- of detacheringsvariant wordt ook wel intra-concern detachering genoemd ${ }^{55} \mathrm{Op}$ grond van artikel 7:691 lid $6 \mathrm{BW}$ zijn de in artikel 7:691 BW opgenomen bijzondere regels voor de uitzendovereenkomst niet van toepassing op 'uitzendovereenkomsten waarbij de werkgever en de derde in een groep zijn verbonden als bedoeld in artikel 24b van Boek 2 dan wel de één een dochtermaatschappij is van de ander als bedoeld in artikel 24a van Boek 2. ${ }^{56}$ Uit de memorie van toelichting bij deze bepaling blijkt dat met deze uitsluiting werd beoogd te voorkomen dat 'arbeidsorganisaties' via een eigen uitzendbureau personeel ter beschikking van de eigen organisatie konden stellen, maar dan met minder verplichtingen, en werknemers van de ene naar de andere eenheid konden worden verschoven om zodoende opbouw van rechten te voorkomen. ${ }^{57}$ Omdat de intra-concern detacherende groepsmaatschappij geen allocatiefunctie vervult op de arbeidsmarkt, werd intraconcern detachering uitgesloten in artikel 7:691 lid 6 $\mathrm{BW}$, zo deelde de regering mee. ${ }^{58} \mathrm{Nu}$ de allocatiefunctie op grond van het hiervoor besproken Care4Care-arrest van de Hoge Raad van 4 november 2016 geen vereiste (meer) is voor de toepassing van de definitie van artikel 7:690 BW en het begrip 'uitzendovereenkomst' in artikel 7:691 BW naar het oordeel van de Hoge Raad geen andere betekenis heeft dan in artikel 7:690 BW, is het de vraag of intra-concern detachering wel kwalificeert als uitzendovereenkomst in de zin van artikel 7:690 BW.

55. Zie over intra-concern detachering J.P.H. Zwemmer, 'Over het werkgeverschap van de personeelsvennootschap en groepsaansprakelijkheid bij het intra-concern detacheren van werknemers', Ondernemingsrecht 2016/78 en par. 6.7 e.v. van mijn dissertatie.

56. Art. 1 lid 3 onderdeel c Waadi bevat een bepaling waarmee hetzelfde werd beoogd voor de toepassing van de Waadi.

57. Kamerstukken I/ 1996/97, 25263, 3, p. 10.

58. Kamerstukken I/ 1996/97, 25263, 3, p. 10 en 34. 
Dat zou niet het geval zijn wanneer de groepsmaatschappij waarbij de werknemer intra-concern wordt gedetacheerd, niet kan worden aangemerkt als 'derde' in de zin van artikel 7:690 BW. Indien intra-concern detachering wel zou worden gekwalificeerd als uitzending in de zin van artikel 7:690 BW, dan zou, ondanks het bepaalde in artikel 7:691 lid $6 \mathrm{BW}$, op grond van artikel 7:668a lid 5 onderdeel a BW een deel van het verlichte ontslagregime wel van toepassing zijn bij intra-concern detachering. ${ }^{59}$

\section{Conclusie}

Aan het door de werknemer in dienst van de werkgever verrichten van arbeid in de zin van artikel 7:610 BW ligt het uitgangspunt ten grondslag dat de werkgever de eigenaar of exploitant is van de onderneming waarin de werknemer de arbeid verricht. De werkgever en de werknemer zijn als partijen bij de arbeidsovereenkomst op grond van artikel 7:610 BW gehouden de in die hoedanigheid voor hen geldende voorschriften in Titel 7.10 $\mathrm{BW}$ na te leven. In verscheidene voorschriften in Titel $7.10 \mathrm{BW}$ is de daarin neergelegde arbeidsrechtelijke bescherming van de werknemer gekoppeld aan de door de werknemer in de onderneming van de werkgever verrichte arbeid. Wanneer op grond van door partijen gemaakte afspraken de contractuele werkgever een ander is dan de eigenaar of exploitant van de onderneming (de feitelijke werkgever) waarin de werknemer de arbeid verricht, kan dit ten koste gaan van de arbeidsrechtelijke bescherming van de werknemer. In geval van een dergelijke driehoeksrelatie kan op grond van artikel 7:610 BW, in weerwil van de door partijen gemaakte afspraken, door de rechter worden geoordeeld dat een arbeidsovereenkomst tot stand is gekomen met de feitelijke werkgever en niet met de contractuele werkgever. Dat kan aan de orde zijn wanneer met de driehoeksrelatie hoofdzakelijk werd beoogd aan het juridische werkgeverschap verbonden verplichtingen weg te contracteren naar een verder inhoudsloze werkgever.

Indien sprake is van een uitzendovereenkomst in de zin van artikel 7:690 BW wordt binnen de driehoeksrelatie tussen de uitzendwerkgever, de opdrachtgever en de uitzendwerknemer, de uitzendwerkgever juridisch geduid als de werkgever van de onder het feitelijke gezag van de opdrachtgever werkzame uitzendwerknemer. De door uitzendbureaus op de arbeidsmarkt vervulde allocatiefunctie vormde de reden voor het opnemen van deze bijzondere regeling van de uitzendovereenkomst in Titel 7.10 BW. Destijds, in de jaren negentig van de vorige eeuw, werd onderscheid gemaakt tussen het kortdurend uitzenden van personeel door uitzendbureaus dat toen aan een vergunning was gebonden en het meer bestendige in- en uitlenen van werknemers

59. Zie over andere gevolgen van een kwalificatie van intra-concern detachering als uitzendovereenkomst in de zin van art. 7:690 BW mijn noot onder JAR 2015/303. door uitleen- en detacheerbedrijven. De regeling van de uitzendovereenkomst zou ook voor deze laatste vormen van terbeschikkingstelling van werknemers gaan gelden, mits dit eveneens geschiedde in het kader van door deze uitleen- of detacheerbedrijven op de arbeidsmarkt vervulde allocatiefunctie. Dit element werd echter niet opgenomen in de definitie van de uitzendovereenkomst in artikel 7:690 BW. Een verklaring hiervoor kan zijn dat ook deze uitleen- en detacheerbedrijven doorgaans een allocatiefunctie vervulden op de arbeidsmarkt en daardoor de aanwezigheid van een allocatiefunctie destijds een vanzelfsprekendheid vormde in relatie tot het beroepsmatig ter beschikking stellen van werknemers. Ingegeven door motieven als risicobeperking en de steeds zwaardere last die het werkgeverschap sindsdien is gaan vormen voor ondernemers, zijn, aangetrokken door de zekerheid van de juridische duiding van de werkgever in artikel 7:690 BW en het hiermee gepaard gaande verlichte ontslagregime, driehoeksrelaties onder de noemer payrolling ontstaan. Deze zijn gericht op het door de ondernemer (of overheidsinstelling) uitbesteden van het werkgeverschap aan werkgevers die uitsluitend fungeren als juridisch en administratief werkgever van de bij de ondernemer werkzame werknemers. Hierbij is geen sprake van de in de wetsgeschiedenis bedoelde allocatiefunctie van de ter beschikking stellende werkgever.

In het Care4Care-arrest heeft de Hoge Raad op grond van de tekst van artikel 7:690 $\mathrm{BW}$ en onder verwijzing naar een uit de context gehaalde passage uit de wetsgeschiedenis geoordeeld dat voor de toepassing van de regeling van de uitzendovereenkomst niet vereist is dat de ter beschikking stellende werkgever een allocatiefunctie vervult op de arbeidsmarkt. De Hoge Raad bevestigt in zijn arrest niet dat bij payrolling telkens sprake is van een uitzendovereenkomst. Artikel 7:690 $\mathrm{BW}$ is, evenals artikel 7:610 $\mathrm{BW}$, van dwingend recht. Daar verandert het arrest van de Hoge Raad niets aan. Partijen kunnen dus niet contractueel afspreken dat bij payrolling sprake is van een uitzendovereenkomst ex artikel 7:690 BW. Daarvoor moet zijn voldaan aan de elementen in de definitie van de uitzendovereenkomst. Dat het payrollbedrijf en de werknemer een schriftelijke arbeidsovereenkomst ondertekenen, impliceert niet dat daarmee vaststaat dat tussen hen een arbeidsovereenkomst tot stand is gekomen en het payrollbedrijf voor de toepassing van artikel 7:690 BW kwalificeert als een werkgever die zijn werknemer ter beschikking stelt. Het is de vraag of bij de thans meest gebruikelijke vorm van payrolling een arbeidsovereenkomst tot stand komt tussen het payrollbedrijf en de werknemer en daarmee of sprake is van terbeschikkingstelling van een werknemer van het payrollbedrijf aan de opdrachtgever in de zin van artikel 7:690 BW. Voor het werkgeverschap van het payrollbedrijf voor de toepassing van Titel $7.10 \mathrm{BW}$ is naar mijn mening in ieder geval meer vereist dan een 'papieren' constructie op basis waarvan het juridische werkgeverschap wordt weggecontracteerd naar een 'papieren werkgever' die bij de totstandkoming en uit- 
voering van de arbeidsovereenkomst geen zelfstandige en inhoudelijke rol speelt. Van een dergelijke zelfstandige en inhoudelijke rol zou sprake kunnen zijn wanneer de focus van de dienstverlening door het payrollbedriif niet uitsluitend is gericht op het fungeren als juridisch en administratief werkgever van de werknemers van derden. Waar het bij een overheidsinstelling of grote onderneming de vraag zal zijn waarom een payrollconstructie nodig is, zou daarvan in het midden- en kleinbedrijf wel zelfstandige inhoud en betekenis kunnen uitgaan. Dan zou het werkgeverschap van het payrollbedrijf ook van toegevoegde waarde kunnen zijn voor de werknemer. Dat zou bijvoorbeeld het geval zijn wanneer payrollbedrijven invulling gaan geven aan de rol van werkgever door zorg te dragen voor, en knowhow te creëren op het gebied van, onder meer de (tussentijdse) scholing, de herplaatsing en, in geval van arbeidsongeschiktheid, de re-integratie van de payrollwerknemer. In dat geval zou - in lijn met het Care4Care-arrest - sprake zijn van een uitzendovereenkomst en het daarbij horende verlichte ontslagregime van toepassing zijn. Daardoor kunnen met de werknemer in beginsel gedurende vijfenhalf jaar flexibele arbeidsovereenkomsten worden gesloten. Anders dan voor een echte uitzendkracht zal daarbij einde inleenopdracht al snel einde arbeidsovereenkomst betekenen omdat de werknemer niet in dienst is van een uitzendwerkgever met een allocatiefunctie op de arbeidsmarkt.

Als de wetgever van oordeel is dat het verlichte ontslagregime bij uitzending niet van toepassing dient te zijn bij payrolling, maar meent dat de payrollwerknemer hier in dezelfde positie behoort te verkeren als een 'gewone' werknemer die rechtstreeks in dienst is of zou zijn geweest van de opdrachtgever, dient hij aan de definitie van de uitzendovereenkomst in artikel 7:690 BW toe te voegen dat de werkgever een allocatiefunctie moet vervullen op de arbeidsmarkt. Naast de hiervoor besproken wetsgeschiedenis kan als argument voor een dergelijke wetswijziging worden aangevoerd dat in de Ontslagregeling de ontslagbescherming van de payrollwerknemer met een arbeidsovereenkomst voor onbepaalde tijd wel is gelijkgetrokken met die van een gewone werknemer wegens het ontbreken van een allocatiefunctie bij het payrollbedrijf. Een dergelijke wetswijziging valt echter op de korte termijn niet te verwachten. In reactie op Kamervragen naar aanleiding van het Care4Care-arrest heeft de minister van SZW weliswaar meegedeeld dat uit de wetsgeschiedenis volgt dat het oordeel van de Hoge Raad niet aansluit bij wat destijds door de wetgever is beoogd, maar daar meteen aan toegevoegd dat een wetswijziging niet meer in zijn kabinetsperiode verwezenlijkt zou kunnen worden. Daarover zullen in een volgend regeerakkoord afspraken gemaakt moeten worden, aldus de minister.

De toepassing van het verlichte ontslagregime is echter niet het enige dat knelt bij payrolling. Doordat de contractuele werkgever bij payrolling een ander is dan de eigenaar of exploitant van de onderneming waarin hij de arbeid verricht, zou de in verschillende bepalingen in en buiten Titel $7.10 \mathrm{BW}$ neergelegde arbeidsrechtelijke bescherming die is gekoppeld aan het werkgeverschap van de eigenaar of exploitant van de onderneming waarin de werknemer de arbeid verricht, hier niet het daarmee beoogde effect hebben. In dat kader kunnen onder andere worden genoemd de verplichtingen van de werkgever op grond van artikel 7:611 BW (recht op tewerkstelling), de overgang van de uit de arbeidsovereenkomst voortvloeiende rechten en verplichtingen bij overgang van onderneming op grond van artikel 7:663 BW en de toepassing van de Wet flexibel werken en de Wet arbeid en zorg. De payrollconstructie heeft eveneens gevolgen voor de toepasselijkheid van (algemeen verbindend verklaarde) cao's. Het payrollbedrijf is slechts verplicht een cao toe te passen wanneer het zelf aan die cao is gebonden of wanneer zijn onderneming of activiteit onder de werkingssfeer valt van een algemeen verbindend verklaarde cao. Daardoor zouden payrollwerknemers weliswaar recht hebben op in die cao opgenomen primaire arbeidsvoorwaarden (artikel 8 Waadi), maar kunnen zij in beginsel geen beroep doen op in de cao gemaakte afspraken die specifiek betrekking hebben op het werken in een onderneming als die van de opdrachtgever (zoals voorzieningen op het gebied van kinderopvang en scholing) of op deelname aan een voor die opdrachtgever verplichtgesteld bedrijfstakpensioenfonds. Een pensioen bij StiPP (het verplichtgestelde pensioenfonds in de uitzendbranche) zal dan een schrale troost zijn voor de payrollwerknemer. 